Sociedlad de Estudios de Hïstoria Agraria - Documentos de Trabajo

DT-SEHA n. 2001

Enero de 2020

www.seha.info

\title{
AGRICULTURAL EXPORTS AND ECONOMIC DEVELOPMENT IN SPAIN DURING THE FIRST WAVE OF GLOBALISATION
}

María-Isabel Ayuda and Vicente Pinilla*

* Universidad de Zaragoza

Contacto: vpinilla@unizar.es

(C) Enero de 2020, María-Isabel Ayuda and Vicente Pinilla ISSN: 2386-7825 


\begin{abstract}
The objective of this article is to study the evolution of Spanish agricultural exports, their share of agricultural production as a whole, the determinants of their expansion and, finally, the contribution that they have made to economic development. Our results show considerable dynamism in agricultural exports, which however faced certain obstacles that limited any further expansion. Their share on production varied greatly, but for some relevant products it was fundamental, substantially contributing to its growth. The increase in external demand but also the comparatively high profitability of export products and a high level of competitiveness in the international market generated highly dynamic behaviour in supply. The contribution of the export sector to Spanish economic growth was positive although moderate. It contributed to financing necessary imports during the industrialisation process, favoured a more efficient allocation of resources and produced intersectoral linkages. However, the geographical concentration of production for export limited its spatial impact on the Spanish economy.
\end{abstract}

Keywords: agricultural development, agricultural trade, Spanish economic history, first wave of globalisation

\title{
Resumen
}

El objetivo de este artículo es estudiar la evolución de las exportaciones agrarias españolas, su participación en el conjunto de la producción agraria, los factores determinantes de su expansión y, finalmente, la contribución que han hecho al desarrollo económico. Nuestros resultados muestran un considerable dinamismo en las exportaciones agrarias que, sin embargo, se enfrentaron a ciertos obstáculos que limitaron su expansión. Su participación en la producción varió mucho, pero para algunos productos relevantes era fundamental y contribuyó sustancialmente a su crecimiento. El aumento de la demanda externa, pero también la rentabilidad comparativamente alta de los productos de exportación y un alto nivel de competitividad en el mercado internacional generaron un comportamiento muy dinámico de la oferta. La contribución del sector exportador al crecimiento económico español fue positiva, aunque moderada. Contribuyó a financiar las importaciones necesarias durante el proceso de industrialización, favoreció una asignación más eficiente de los recursos y produjo vínculos intersectoriales. Sin embargo, la concentración geográfica de la producción destinada a la exportación limitó su impacto espacial en la economía española.

Palabras clave: desarrollo agrario, comercio agrario, historia económica española, primera globalización

JEL CODES: N53, N73, O13, Q17 


\section{Introduction ${ }^{1}$}

The role played by agriculture in Spain's economic development constituted a central issue in the debate among economic historians in the 1970s and $1980 \mathrm{~s}^{2}$. The view of a backward economy in which the industrial revolution had failed consolidated quickly. Agriculture was considered to have played a determining role in this failure because, as a market, it had not been able to stimulate industrialisation due to its low technological development and the passive nature of the farmers who had no interest in innovation and who were unreceptive to market signals (Nadal, 1975). In short, as the majority of the population and the economic activity were linked to the agricultural sector, its low level of demand was responsible for the economic backwardness of the country.

The absence of sufficiently solid empirical data to verify this hypothesis gave rise to intense efforts to quantitatively estimate agricultural production from the end of the nineteenth century, which is for when the earliest data could be obtained, until the Spanish Civil War of 1936-1939 (Grupo de Estudios de Historia Rural, 1983 and 1991; Simpson, 1995). The new available data showed an increase in production and productivity which was at odds with the image of stagnation that had prevailed until then. On the contrary, particularly in the first third of the twentieth century, a rapid advance in production and productivity could be detected which compared favourably with other European agricultural sectors (Grupo de Estudios de Historia Rural, 1983; Jiménez Blanco, 1986). Other studies have also reviewed the events of the nineteenth century, appreciating a significant growth of total factor productivity (Bringas, 2000; Lana, 2011). The new view of the contribution of agriculture to economic development indicates environmental constraints, particularly the aridity and roughness of the terrain, trade restrictions and a greater increase in agricultural exports and the low labour productivity as limiting factors but not decisive obstacles to economic growth (Gallego, 2001). Great emphasis has also been placed on the low level of development of industry and its low capacity to draw the active rural population towards the towns as a key element that limited the improvement of agricultural productivity. Some economic historians have particularly highlighted the

\footnotetext{
${ }^{1}$ This study has received financial support from the Ministry of Science, Innovation and Universities of Spain, project PGC2018-095529-B-I00 and from the Government of Aragon, through the Research Groups, S40_17R and S55_17R and FEDER. The authors wish to thank Pablo Castro, Domingo Gallego, Ramon Ramon and participants at the Rural History Conferences (Bern, 2013 and Paris, 2019) for their comments. ${ }^{2}$ On the debate, see Iriarte and Pinilla (2019).
} 
low dynamism of the industrial sector and its excessive orientation towards the domestic market as key factors for understanding the difficulties to increase the exodus of the rural workforce which would have stimulated a faster technological change and the consequent growth in productivity (Prados de la Escosura, 1988; Silvestre, 2005).

Agricultural progress was also limited by certain institutional obstacles, such as the unequal distribution of property or the very low development of the financial system that was unable to provide the necessary agricultural finance at a reasonable cost (Clar and Pinilla, 2009).

In short, in view of the extensive European revisionist literature (Lains and Pinilla, 2009), the perception of the role of agriculture in economic development has shifted towards a view that considers that although the agriculture sector was not able to lead the development process it was not responsible for Spain's backwardness. This shows that the modernisation of the Spanish economy advanced until the years of the Civil War or the Second World War, although at a slow rate.

Within this context, the export sector is particularly noteworthy for being the most dynamic within Spanish agriculture (Pinilla, 2001). The exports of food and agricultural products grew substantially during the first wave of globalisation and were particularly important for the international integration of the Spanish economy (Prados de la Escosura, 1982; Gallego and Pinilla, 1996). Therefore, the objective of this article is to study the evolution of Spanish agricultural exports, their weight of the agricultural production as a whole, the determinants of their expansion and, finally, the contribution that they made to economic development.

Our results show an important dynamism of agricultural exports, which however faced certain obstacles that limited any further expansion. Although their share of production as a whole was not too big, for some relevant products it was essential, substantially contributing to growth. The increase in external demand but also the comparatively high profitability of the export products and a high level of competitiveness on the international market generated a highly dynamic behaviour of supply. The contribution to economic development, while substantial, particularly through the obtaining of currencies and the dynamism of certain activities with relevant carry-over effects, was limited due to its moderate share of agricultural production. 
After this introduction, the article begins by studying the evolution of exports and their composition. Subsequently, it quantifies their importance in the expansion of output. The following section analyses the principal determinants of export growth. In the fifth section we study the principal economic impacts of agricultural exports and in the final section we draw the main conclusions.

\section{The evolution and composition of exports of food and agricultural products}

Exports of Spanish food and agricultural products grew in the period of the first globalisation at an average annual rate of $2.5 \%^{3}$. However, as we can see in Graph 1 , the growth rate was significantly higher in the second half of the nineteenth century, (particularly from approximately 1870 until 1891)than later. 1891 was a significant year because, as we shall see later, from this year, wine exports to France, which had accounted for much of the strong growth in this first sub-period, began to suffer from strong protectionist measures in this country, so exports as a whole fell sharply. Therefore, the growth in the years 1849-1891 was notably higher than that of the period 1891-1928; with an average annual rate of $3.6 \%$ as opposed to $1.2 \%$.

Figure 1. Evolution of Spanish Agricultural Exports

(volume index, 1926-35 = 100) (at 1910 prices)

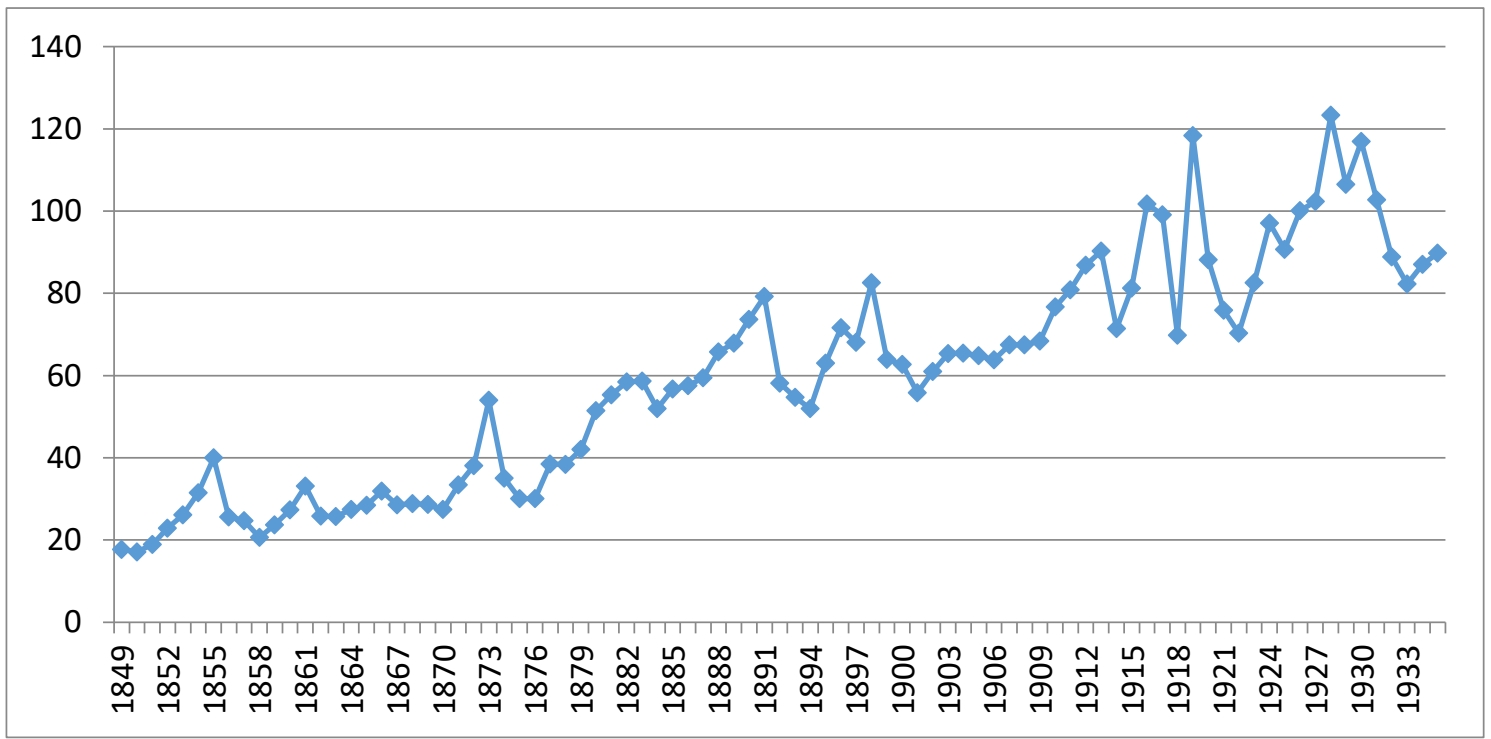

Source: Own calculation is based on Estadística del Comercio Exterior de España.

\footnotetext{
${ }^{3}$ For this calculation we have considered the period 1849 (first year for which there are data available in the Spanish foreign trade statistics) until 1928 (historical maximum of Spanish agricultural exports before the collapse of the first wave of globalisation from 1929).
} 
The deceleration of the growth rate of Spanish agricultural exports fully coincided with that of the international trade. The average annual growth rate of global agricultural exports between 1850 and 1902 was 3.7\% (almost identical to the Spanish rate) while between 1902 and 1938 it only reached 1.4\% (Aparicio, Pinilla and Serrano, 2018). From 1929, Spanish exports shrank significantly as a consequence of the economic crisis and the measures taken by many countries to restrict trade (Hynes, Jacks and O’Rourke, 2012, Bromhead, Fernihough, Lampe and O'Rourke, 2019; Hernández and Pinilla, 2013).

Table 1. Breakdown of exports at current values (\%)

\begin{tabular}{|c|c|c|c|c|c|c|}
\hline & $\begin{array}{l}1849- \\
69\end{array}$ & $\begin{array}{l}1870- \\
90\end{array}$ & $\begin{array}{l}1891- \\
913\end{array}$ & $\begin{array}{l}1914- \\
20\end{array}$ & $\begin{array}{l}1921- \\
28\end{array}$ & $\begin{array}{l}1929- \\
35\end{array}$ \\
\hline FRUITS, GRAPES \& OLIVES & 2.6 & 4.7 & 14.8 & 11.3 & 20.0 & 31.1 \\
\hline NUTS \& RAISINS & 10.7 & 8.8 & 9.3 & 7.3 & 9.2 & 9.5 \\
\hline FRESH VEGETABLES & 0.6 & 0.7 & 3.5 & 4.7 & 6.5 & 7.4 \\
\hline $\begin{array}{l}\text { UNPROCESSED } \\
\text { AGRICULTURAL PROD. }\end{array}$ & 22.4 & 18.8 & 32.8 & 31.7 & 42.3 & 51.4 \\
\hline $\begin{array}{l}\text { UNPROCESSED LIVESTOCK } \\
\text { PROD. }\end{array}$ & 7.8 & 6.1 & 8.8 & 4.6 & 2.3 & 1.1 \\
\hline $\begin{array}{l}\text { UNPROCESSED FORESTRY } \\
\text { PROD. }\end{array}$ & 3.0 & 3.1 & 2.3 & 1.6 & 1.6 & 1.3 \\
\hline WINE & 40.1 & 54.7 & 24.9 & 23.9 & 19.6 & 12.8 \\
\hline OLIVE OIL & 7.7 & 4.0 & 6.5 & 11.1 & 10.0 & 11.7 \\
\hline PROCESSED AGRIC.PROD. & 59.1 & 62.9 & 32.7 & 37.4 & 30.4 & 24.7 \\
\hline $\begin{array}{l}\text { PROCESSED LIVESTOCK } \\
\text { PROD. }\end{array}$ & 1.3 & 1.9 & 4.6 & 6.6 & 4.8 & 4.7 \\
\hline PROCESSED FORESTRY PROD. & 4.9 & 4.9 & 11.3 & 8.4 & 9.2 & 7.8 \\
\hline $\begin{array}{l}\text { PRESERVED MEATS \& } \\
\text { VEGETABLES }\end{array}$ & 0.9 & 1.6 & 4.0 & 3.3 & 3.3 & 3.5 \\
\hline FISH & 0.6 & 0.7 & 3.4 & 6.3 & 6.2 & 5.6 \\
\hline TOTAL & 100.0 & 100.0 & 100.0 & 100.0 & 100.0 & 100.0 \\
\hline
\end{tabular}

The composition of exports for each period has been calculated as an average of the annual composition for the corresponding years.

Source: We have based our calculation of these figures on the Estadísticas del Comercio Exterior de España, 1849-1935.

The expansion of exports was fuelled by a wide variety of products, although there was an important change in the composition of the most prominent products in the two sub-periods that we have described. Wine was the leading product in the period between 1849 and 1891, when it represented more than half of food and agricultural exports (Table 1). Nuts and raisins and olive oil were the next most exported products during this period. 
The expansion of wine exports was mainly based on the growing French demand, particularly when the arrival of the phylloxera plague to this country caused its production to fall drastically. The supply of the domestic market and the maintenance of its exports required France to import a high volume of wine and Spain became its principal supplier (Lachiver, 1988; Pan-Montojo, 1994; Chevet, Fernández; Giraud-Héraud and Pinilla, 2018).

The recovery of production in France, after it had replanted is vineyards with American vines immune to the plague, did not imply a sharp fall in imports in the short term, as the hybrids initially used in this replanting produced wine with a pale colour and a low alcohol content, so it was necessary to mix it with wines with a higher alcohol content and a more intense colour, such as those from Spain. However, the development of the French colonisation in Algeria and the rapid expansion of wine-growing by colonists from the mother country, led to a customs policy that punished the imports from third countries, especially Spain which was its principal supplier, and allowed Algerian wine to enter France practically free of duties, which quickly replaced Spanish wine (Pinilla and Ayuda, 2002). The colonisation policy played a crucial role in this expansion of wine production (Maravall, 2019). Spanish wine found itself in a very vulnerable position and its sales to France varied wildly depending on the French harvest and that of its North African colony. But Spanish wine also faced considerable problems in other markets into which it had expanded. In the American continent, the protectionist measures to promote domestic production, both in the United States and in other countries such as Argentina or Uruguay, led to a strong fall in Spanish exports. In the markets of the industrialised countries with higher income levels, exports were enormously limited as wine had not become a mass consumer product due to a preference by their populations for other alcoholic drinks such as beer or spirits (Anderson, Nelgen and Pinilla, 2017; Anderson, Meloni, and Swinnen, 2018). These difficulties for wine in external markets are fundamental for explaining the lower growth rate of agricultural exports in the first third of the twentieth century, given the enormous share that this product had of them.

From the last decade of the nineteenth century, fresh fruit and vegetables (Mediterranean Horticultural Products, hereafter MHPs) were the products that led export growth. From representing a very small percentage of exports in the mid-nineteenth century, they grew to almost $40 \%$ of them. Wine was a very traditional export product in Spain and highly adapted to the country's agro-climatic conditions as grapes are a dry 
crop. Fresh fruit and vegetables, on the other hand, require abundant sunlight, which Spain has plenty of and a lot of water, which was not feasible in a semi-arid country. Therefore, different irrigation works had to be undertaken in order to supply these crops with water. In this case, the principal markets for these exports were the northern European countries, in which the increase in income translated into a greater than proportional increase in the demand for these products ${ }^{4}$. Another product whose exports also rose slightly was olive oil. In this case, despite the problems encountered at the end of the nineteenth century due to the competition from synthetic oils for industrial uses, from 1914, new refining technology enabled a strong expansion of its exports in the first third of the twentieth century. As in the case of wine, in this case, the principal client was also a large producer, Italy, which subsequently often re-exported it after re-bottling it.

Table 2. Spain in the international trade of selected agricultural products

MEDITERRANEAN HORTICULTURAL

PRODUCTS

\begin{tabular}{|c|c|c|c|c|c|c|}
\hline & & & $\begin{array}{c}1909- \\
13\end{array}$ & $1925-8$ & $\begin{array}{c}1929- \\
32\end{array}$ & $1933-5$ \\
\hline $\begin{array}{l}\text { Spanish share of World } \\
\text { Trade }\end{array}$ & n.a. & n.a. & 35 & 35 & 38 & 32 \\
\hline $\begin{array}{l}\text { Exports Spain Index } \\
\text { numbers }\end{array}$ & n.a. & n.a. & 100 & 130 & 159 & 151 \\
\hline $\begin{array}{l}\text { Exports World Index } \\
\text { numbers }\end{array}$ & n.a. & n.a. & 100 & 127 & 145 & 162 \\
\hline \multicolumn{7}{|c|}{ WINE } \\
\hline & $1865-8$ & $\begin{array}{c}1888- \\
91\end{array}$ & $\begin{array}{c}1909- \\
13\end{array}$ & $1924-8$ & $\begin{array}{c}1928- \\
32\end{array}$ & $\begin{array}{c}1933- \\
35\end{array}$ \\
\hline $\begin{array}{l}\text { Spanish share of World } \\
\text { Trade }\end{array}$ & 22 & 53 & 19 & 23 & 19 & 9 \\
\hline Spain Index numbers & 43 & 308 & 100 & 131 & 118 & 57 \\
\hline World Index numbers & 37 & 110 & 100 & 109 & 122 & 119 \\
\hline
\end{tabular}

\begin{tabular}{|l|r|r|r|r|r|r|}
\hline \multicolumn{1}{c|}{ OLIVE OIL } \\
\cline { 2 - 7 } & $1865-8$ & $\begin{array}{c}1888- \\
91\end{array}$ & $\begin{array}{c}1909- \\
13\end{array}$ & $1924-8$ & $\begin{array}{c}1928- \\
32\end{array}$ & $\begin{array}{c}1933- \\
35\end{array}$ \\
\hline $\begin{array}{l}\text { Spanish share of World } \\
\text { Trade }\end{array}$ & 21 & 15 & 31 & 37 & 33 & 32 \\
\hline Spain Index numbers & 53 & 43 & 100 & 205 & 201 & 538 \\
\hline World Index numbers & 82 & 87 & 100 & 171 & 187 & 168 \\
\hline
\end{tabular}

a Index numbers (base 1909-1913 = 100)

Source: Mediterranean horticultural products (Pinilla and Ayuda, 2009); Wine (Anderson and Pinilla, 2017); Olive oil (Ramon-Muñoz, 2010)

\footnotetext{
${ }^{4}$ It has been estimated that the elasticity of demand for oranges (the most important of the exported MHPs) with respect to income was 3.05 for the period 1854-1896 and 1.44 for the years 1896-1935 (Pinilla and Ayuda, 2008, p. 588).
} 
In the three most important product groups in terms of exporting expansion, Spain reached a significant share of global trade, despite the enormously competitive markets (Table 2). Both in MHPs and olive oil, this share oscillated at around 33\% of world trade, which shows a very solid position. In the case of wine, the share varied quite a lot, but normally oscillated between $20 \%$ and $50 \%$.

\section{How much did agricultural exports contribute to output growth?}

It is important to know the extent to which the exporting expansion was relevant in order to explain the growth of Spanish agricultural production. Therefore, first we have estimated the ratio of exports to production for the years 1860, 1900 and 1930 (Table 3). The calculation is made at fixed 1910 prices for exports and for production. The table shows that, for all of the years studied, the exported amounts represented extremely varied percentages of production of the different products ${ }^{5}$.

Table 3. Ratio of agricultural exports to production (\%)

\begin{tabular}{|l|c|c|c|c|c|c|c|c|c|}
\hline & Cereals\&Pulses & $\begin{array}{c}\text { Nuts \& } \\
\text { Raisins }\end{array}$ & $\begin{array}{c}\text { Fruits \& } \\
\text { Grapes }\end{array}$ & $\begin{array}{c}\text { Fresh } \\
\text { vegetables }\end{array}$ & Wine & $\begin{array}{c}\text { Olive } \\
\text { oil }\end{array}$ & $\begin{array}{c}\text { Other } \\
\text { agric. }\end{array}$ & Livestock & Total \\
\hline 1860 & 4.6 & 44.9 & 3.6 & 0.5 & 9.9 & 5.5 & 4.4 & 1.6 & 4.6 \\
\hline 1900 & 0.6 & 17.5 & 26.7 & 2.2 & $* 38.1$ & 12.0 & 7.7 & 5.5 & 6.7 \\
\hline 1930 & 1.3 & 16.1 & 56.7 & 3.9 & 15.8 & 21.3 & 4.2 & 1.0 & 8.0 \\
\hline
\end{tabular}

(*) 1891. In 1900 was $15.3 \%$.

Source: Own calculation based on Estadística del Comercio Exterior de España (exports) and Grupo de Estudios de Historia Rural (1983) (production). It is an approximate calculation as in the case of production, with the exception of wine and oil, products without industrial processing are included and the exports also include processed agricultural products.

We can observe highly significant differences between the most important products in exports and the rest. Therefore, the very high share of production that exports represented of wine, MHPs or olive oil contrast with the very low weight of the main product of Spanish agriculture: cereals. The same occurred with livestock production, in which exports also accounted for a very low percentage of production. It should be taken into account that cereals and livestock products were very important as in 1900 they

\footnotetext{
5 The ratio of agricultural imports to production was similar, although slightly lower (Pinilla, 1995: 166; Gallego, 2001: 156).
} 
represented 32\% and 27\% of final agricultural production, respectively (Simpson, 1994). In short, Spain was not a competitive producer of cereals or livestock products given its agro-climatic characteristics, and its production per hectare was very low (González de Molina, 2001).

We can further our understanding of the contribution of the exporting boom to the increase in production if we estimate what part of the latter was due to the increase in exports. For the agricultural sector as a whole, this contribution was modest, as we can place it at around 11\%; a little more for the second half of the nineteenth century and less for the first third of the twentieth century. Furthermore, if we break down the estimate by groups of products (for those for which it is possible), the contrasts are enormous (Table 4). In the principal export products, this contribution was fundamental, particularly in the case of the MHPs, but it was also significant for olive oil and wine. However, for other products it was much less significant.

Table 4. Contribution of foreign demand to the growth of production, 1860-1930 (\%)

\begin{tabular}{|c|c|c|c|r|r|r|r|r|r|}
\cline { 2 - 10 } \multicolumn{1}{c|}{} & $\begin{array}{c}\text { Cereals \& } \\
\text { Pulses }\end{array}$ & $\begin{array}{c}\text { Nuts \& } \\
\text { Raisins }\end{array}$ & $\begin{array}{c}\text { Fruits \& } \\
\text { Grapes }\end{array}$ & $\begin{array}{c}\text { Fresh } \\
\text { vegetables }\end{array}$ & Wine & Olive oil & $\begin{array}{c}\text { Other } \\
\text { agric. }\end{array}$ & Livestock & Total \\
\hline $1860-1900$ & -32.8 & 10.7 & 58.7 & 4.4 & $* 21.4$ & 31.3 & 12.8 & 37.6 & 12.2 \\
\hline $1900-1930$ & 3.1 & 14.0 & 105.2 & 6.1 & 8.0 & 31.5 & 1.1 & -6.0 & 10.6 \\
\hline
\end{tabular}

a. In order to calculate the contribution, we have used the following formula:100* (Xt-Xi) / (Yt-Yi). Where $\mathrm{Xi}$ and $\mathrm{Yi}$ are the exports and total production in the initial year and $\mathrm{Xt}$ and $\mathrm{Yt}$ the exports and total production in the final year. Exports and production are valued at 1910 prices, which, for the total, generate a downward bias of the results, as the price behaviour of exports was better than that of domestic market prices.

(*) The contribution of foreign demand to the growth of production between 1860 and 1891 was $70.4 \%$. Source: Own calculation based on Estadísticas del comercio exterior de España and Grupo de Estudios de Historia Rural (1983).

\section{The major determinants of export growth}

We can classify the factors that fuelled the growth of Spanish agricultural exports into three groups: demand, supply and those linked to the globalisation process itself. As we shall see below, for the three product groups that accounted for the greatest share in the increase of exports (wine, olive oil and MHPs), the weight of these factors often did not coincide having certain significant differences, although there were also certain similarities.

From the demand perspective, the increase in the income of those countries where it was growing the most due to the development of the industrialisation process is, undoubtedly, the first factor to consider. This improvement in income clearly boosted the 
exports of MHPs. It has been estimated that for the period 1870-1935 each increase of $1 \%$ of global income implied an increase in Spanish exports of MHPs of around 1.3\% (Pinilla and Ayuda, 2010).

However, wine displayed very different dynamics. Although the increase in the populations of the importing countries benefited Spanish exports, the improvement in their income per capita did not (Pinilla and Serrano, 2008). Spanish exports were directed at highly varied markets. In some of them, the increase in the population, where wine was the most important alcoholic drink, facilitated the expansion of exports, but when other alcoholic drinks were preferred by the majority of the population, the improvement in income per capita did not imply a sustained increase in exports in the long term ${ }^{6}$. This occurred in the British or North American markets, where wine was consumed by the small economic elite class and was considered as a luxury product. Only the immigrant population with Mediterranean origin constituted a significant consumer of wine in the United States. In these types of markets, population growth did not lead to an increase in exports.

The case of olive oil is similar to that of wine, as, its market was limited to the Mediterranean area and immigrants from this region in other countries, such as the United States. Therefore, it did not become a product of mass consumption which enormously limited its export growth.

From the demand perspective, another two factors were important to explain the exporting boom. First, as we have already indicated, transatlantic emigration opened up possibilities in the north and south of the American market in order to increase exports. Emigrants conserved the consumption habits of their countries of origin and therefore fostered the increase in exports (Dunlevi and Hutchinson, 1999; Ramon-Muñoz, 2010). In the case of Spain, this was particularly important in the region of the River Plate (Fernández, 2004). Finally, an external and unexpected shock, namely the phylloxera plague to France and the brutal fall in production in this country, generated a rapid increase in Spanish wine exports to France (Chevet et al., 2018; Lachiver, 2009).

From the supply side, it is important to note how certain technological innovations favoured the improvement of exporting possibilities and foreign sales. In the case of the

\footnotetext{
${ }^{6}$ Similarly, French wine exports between 1849 and 1938 were not driven by growth in the income per capita of their trading partners (Ayuda, Ferrer-Pérez and Pinilla, 2019).
} 
MHPs, the most notable was the change in cultivation methods. In the case of fruit trees, the crops changed from trees being planted on the edges of the fields, normally where cereals were grown, so as to complement the basic production of cereals and small vegetable gardens for self-consumption to uniform and specialised plantations of trees and plants for the purpose of selling the produce either in the domestic market or abroad (Garrabou, 1985). At first the traditional irrigation systems could be used, but soon it was necessary to construct new installations to ensure the supply of water (either through well drilling or the construction of canals), the use of fertilizers (first guano and then chemical fertilizers) and the use of machinery to pump water. We can appreciate the size of this transformation process if we take into account that in the two principal orange producing provinces, Castellon and Valencia, the area dedicated to their cultivation grew from 1,249 hectares in 1860 (only ten years after the regular plantations of oranges came into being) to 58,773 in 1932 . Furthermore, the demand for the supply of water required irrigation or well drilling works to be carried out together with the increasing use of machinery and fossil energy sources to pump water (Calatayud and Martínez Carrión, 1999 and 2005). This represented very important changes in soil uses, as the predominant irrigated crops were cereals.

The expansion of exports required an increase in production, which, as we have seen, was significantly driven by the exports in the most relevant products in foreign trade. This increase in production largely took place as a result of the increase in prices of exportable products, with respect to those intended for the domestic market.

In short, farmers increased production by planting vines on land previously used for cereals or on unfarmed land in the case of wine, or for MHPs, investing in new irrigation works, drilling wells or replacing traditional cereal crops, because it was much more profitable. During the great wine growing expansion in the final decades of the nineteenth century, wine prices grew quickly due to French demand. In the case of MHPs, the high elasticity of supply with respect to relative profitability (2.57) clearly shows the importance of changes in this variable for the evolution of supply (Pinilla and Ayuda, 2010). In short, there were high returns compared with those offered by traditional products. Roncalés showed that in 1881, the return per hectare in the Valencia orange groves was 248 per cent higher than the all-crop average in 1881, and approximately 200 per cent higher than the return on any other irrigation-based product (Roncalés, 1998, pp. 186-197). Other studies have also verified the high returns of the orange crop (Garrido, 
2010; Palafox, 1983). The real prices of MHPs as a whole behaved favourably between 1870 and 1935 (Pinilla and Ayuda, 2010).

Finally, the more dynamic growth of exports cannot be explained if we do not contemplate Spain's high level of competitiveness, which ensured it a high market share in these products (Table 2). As already seen, this occurred in the case of wine, not only during the exporting expansion phase, but also in the first third of the twentieth century, when Spanish exports grew more than world exports thanks to their high competitiveness (Pinilla and Ayuda, 2002, pp. 77-78; Tena, 1992, pp. 348-349). The same was the case of olive oil, whose exports were also driven by the competitiveness effect (Tena, $1992 \mathrm{p}$. 349), particularly with respect to the other great world producer, namely Italy, which imported increasing amounts of Spanish oil (Simpson, 1995). Spanish exports in 187074 represented just $37 \%$ of Italian exports, but in 1934-38 they represented $147 \%$ (Ramon-Muñoz, 2000, p. 170). In the case of oranges, we also have evidence that their price on the international market gave them an advantage with respect to technologically more advanced competitors such as California (Pinilla and Ayuda, 2009; Garrido, 2010). Therefore, in 1934 the price of Spanish oranges entering the British market before paying tariffs was approximately $60 \%$ of that of the oranges coming from California or Brazil and $78 \%$ of those from Palestine (Neumark, 1938, p. 113). The lower labour costs constituted one of the main sources of Spain's competitive advantage for both the MHPs competing with those of California and for wine, competing with that of France. Also, in the canning sector, specifically in vegetable preserves, the low prices and high quality of Spanish products explain their extraordinary growth in the first third of the twentieth century (Martínez Carrión, 1989, p. 644).

Finally, the drivers of the first globalisation, trade liberalisation and the reduction in transaction costs favoured, at least initially, the expansion of Spanish exports.

The reduction in transport costs favoured the cheapening of Spanish products in foreign markets. It has been economically verified that this reduction in transport costs fuelled both the supply and demand of MHPs between 1870 and 1935, although its effect was small given the proximity of the principal destination, which was Great Britain (Pinilla and Ayuda, 2010). In the case of Spanish wine, the sensitivity of exports to transport costs has also been verified (Pinilla and Serrano, 2008). French demand even drove the construction of small railway spurs in Spain that connected the producing areas with the main lines enabling the wines to be transported to France. There is also empirical 
evidence of the positive impact that the reduction of the fleets had on France's wine exports (Ayuda et al., 2019).

The role played by international trade liberalisation, principally through the signing of bilateral agreements, was ambivalent. Initially, it clearly favoured Spanish exports of agricultural and food products, but progressively in some important markets, the protectionist wave, initiated at the end of the nineteenth century, negatively affected these exports.

We can clearly see this double role played by tariffs in wine exports. Without a very substantial reduction of the tariffs paid by Spanish wine in the French market, the great exporting expansion beginning in the 1850s would not have taken place, but particularly from the end of the 1870s (Pan-Montojo, 1994). The Italian case shows how the trade war between this country and France, at the critical time of intense demand for wine in the latter due to the phylloxera plague, enormously limited the ability to take advantage of such a relevant circumstance (Loubère, 1978). However, from the end of the century, a radical change in French trade policy with respect to wine to favour the production of its colony Algeria, greatly limited the imports coming from Spain which became enormously irregular as, in the short term, they depended essentially on France's volume of production. Therefore, in France between 1874 and 1934, each one per cent increase in the tariff would reduce the market share of imports by around $1.8 \%$ in the long-term (Pinilla and Ayuda, 2002, pp. 69-75). But Spanish wine also suffered the consequences of the increase in protectionism in the American continent. Countries such as Argentina, Uruguay, Brazil or the United States significantly increased production from the end of the century, which had an important effect on European imports, such as those from Spain (Anderson and Pinilla, 2018). The state implemented an active policy to sign trade agreements that facilitated the entry of Spanish agricultural products in the markets of other countries, although at the cost of facilitating the entrance into Spain of manufactured goods from more industrialised nations (Serrano, 1987). It could be said that this was the main contribution of state action to the expansion of exports.

The tariff problems also clearly affected the MHPs, although mainly in the North American market. Spain's exports of these products were severely harmed by the boom in Californian production and the will of the Congress to reserve the domestic market for it. Therefore, the Spanish producers not only gradually lost the opportunity to expand their sales in a market with a more dynamic behaviour, but these sales fell significantly. 
In citrus fruits alone for the year 1910, it has been estimated that, in the case where protection did not exist in the United States market, Spain's GDP would have increased that year by $0.8 \%$ due to the increase in its exports to this country (Pinilla and Ayuda, 2009, pp. 193-194). The case of protection of citrus fruits was not an exception. From 1924, the market also shut out table grape imports due to supposed health reasons, although the protectionist measures really sought to protect the thriving Californian industry (Sánchez, 1992). However, in the United Kingdom, the principal market of Spanish MHPs, an open market without restrictions to Spanish exporters, was maintained until the depression of the 1930s.

For olive oil, after liberalisation, the northern European markets maintained a low level of protection throughout the period, so their tariffs were not an obstacle for export expansion, rather a favourable element. However, in the American continent, the levels of protection were high, particularly from the end of the nineteenth century. In Latin America, depending on the years and countries, they oscillated between $30-50 \%$ ad valorem and in the United States at around 35\% until the 1930s when they reached values of around $70 \%$. Contrary to the case of wine, the protection of this continent was mainly due to fiscal factors, that is, revenue needs of the governments, although in the United States, the pressure of the Californian producers may also have been significant (RamonMuñoz, 2010, pp. 172-178).

\section{The main economic impacts of export growth}

During the period of study, the agricultural sector was the most important of the Spanish economy, oscillating between a maximum of approximately 40\% of GDP between 1850 and 1880 and a minimum of approximately 25\% in the 1930s (Prados de la Escosura, 2003, pp. 290-292). With the estimates that we have carried out of the weight that exports represented of the whole of agricultural production (Table 3), we can observe that their contribution to economic growth was positive, although moderate. However, the economic impact should take into account the variations in relative prices and, as we have indicated, those of the export products tended to behave in a better way than those of agricultural production as a whole. Therefore, if we take the data of Gallego (2001) referring to production at current values and calculate the ratio between total agricultural exports and final agricultural production, their impact was significant, although highly 
variable due to price fluctuations. Exports represented between $10 \%$ and $20 \%$ of final agricultural production (Figure 2).

Figure 2. Exports/final production ratio at current prices of the Spanish agricultural sector

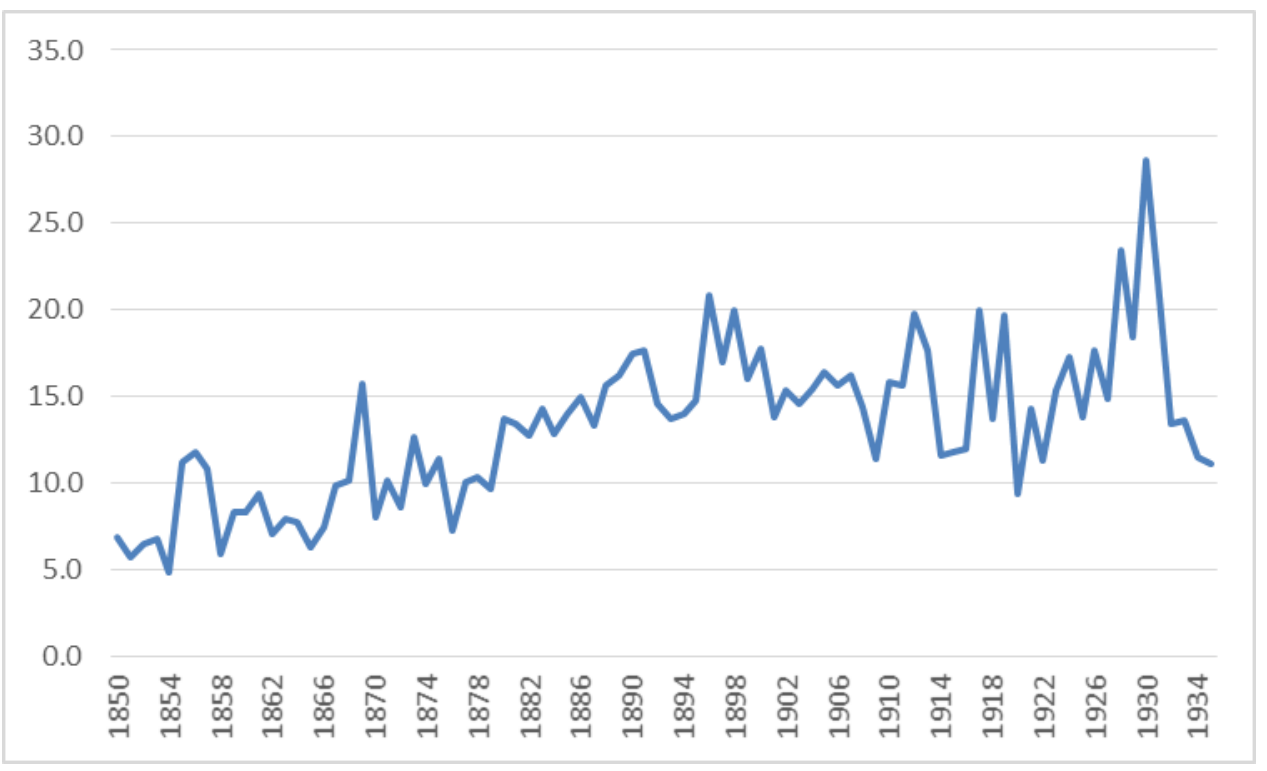

Source: Gallego (2001).

Throughout the period studied, agricultural exports constituted around $70 \%$ of the total exports, in other words, they were decisive for the Spanish foreign trade sector. One of their key contributions was their fundamental role to even out the balance of trade. The agricultural balance of trade had an almost permanent positive sign, except in certain adverse circumstances, and therefore facilitated the financing of the import of certain crucial goods during the Spanish industrialisation process (Gallego and Pinilla, 1996). This positive sign of the agricultural balance of trade was due mostly to fruit and vegetable production and the derived processed products. The imports of livestock products however, significantly exceeded exports (Table 6). 
Table 5. Percentage of exports of agricultural products and foodstuffs of total Spanish foreign trade

\begin{tabular}{|l|l|}
\hline $1849-1869$ & 74.4 \\
\hline $1870-1890$ & 67.2 \\
\hline $1891-1913$ & 49.2 \\
\hline $1914-1920$ & 52.6 \\
\hline $1921-1928$ & 68.3 \\
\hline $1929-1935$ & 76.6 \\
\hline
\end{tabular}

a The percentage for each period is the arithmetical average of the percentages for each year over the official values for foreign trade (in current pesetas for each year).

Source: Agricultural exports calculated on the basis of the Estadísticas del Comercio Exterior de España, 1849-1935. Annual series totals from Tena (1989).

Table 6: Coverage ratio of exports over imports (period averages)

\begin{tabular}{|c|c|c|c|c|c|c|}
\hline & $1849-69$ & $1870-90$ & $1891-913$ & $1914-20$ & $1921-28$ & $1929-35$ \\
\hline $\begin{array}{l}\text { UNPROCESSED AGRICULTURAL } \\
\text { FOODDSTUFFS }\end{array}$ & 200.8 & 186.6 & 171.9 & 156.5 & 226.5 & 428.0 \\
\hline $\begin{array}{l}\text { VEGETABLE TEXTILE FIBRES \& OTHER } \\
\text { AGRIC.PROD. }\end{array}$ & 2.7 & 1.5 & 3.0 & 4.3 & 3.3 & 3.1 \\
\hline UNPROCESSED AGRICULTURAL PROD. & 68.9 & 49.7 & 60.4 & 58.5 & 68.8 & 130.3 \\
\hline LIVESTOCK & 107.0 & 190.2 & 79.3 & 77.2 & 17.0 & 63.3 \\
\hline RAW WOOL & $1,432.4$ & 140.5 & 140.9 & 216.9 & 147.7 & 42.7 \\
\hline UNPROCESSED LIVESTOCK PROD. & 182.0 & $\mathbf{1 1 7 . 2}$ & 78.6 & 103.1 & 32.5 & 12.1 \\
\hline UNPROCESSED FORESTRY PROD. & 51.7 & 49.0 & 24.6 & 39.2 & 15.1 & 15.8 \\
\hline PROCESSED FOODS AND BEVERAGES & 250.8 & 450.6 & $2,524.8$ & $2,135.0$ & $2,963.5$ & $3,911.4$ \\
\hline OLIVE OIL \& OTHER VEGETABLE OILS & $2,063.8$ & 469.6 & $2,483.7$ & $6,416.1$ & $15,836.4$ & $21,795.8$ \\
\hline $\begin{array}{l}\text { MANUFACTURED TOBACCO \& OTHER } \\
\text { PROC. AGRIC. PROD. }\end{array}$ & 4.3 & 0.4 & 0.6 & 21.0 & 0.3 & 0.2 \\
\hline PROCESSED AGRICULTURAL PROD. & 271.9 & 398.5 & 912.9 & $\mathbf{1 , 2 6 4 . 8}$ & 664.7 & $1,149.1$ \\
\hline $\begin{array}{l}\text { MEAT \& OTHER EDIBLE ANIMAL } \\
\text { PRODUCTS }\end{array}$ & 45.0 & 11.3 & 8.6 & 13.9 & 18.6 & 12.5 \\
\hline HIDES, SKINS \&LEATHER & 14.4 & 23.1 & 64.4 & 98.5 & 95.8 & 122.2 \\
\hline PROCESSED LIVESTOCK PROD. & 18.7 & 19.2 & 40.2 & 68.7 & 63.0 & 75.1 \\
\hline PROCESSED FORESTRY PROD. & 180.2 & 132.7 & 270.1 & 339.3 & 403.4 & 517.1 \\
\hline PRESERVED MEATS \& VEGETABLES & 577.4 & 791.5 & $\mathbf{1 , 3 0 3 . 2}$ & $3,484.4$ & $2,110.4$ & 775.2 \\
\hline TOTAL & 117.1 & 116.5 & 95.8 & 121.4 & 89.4 & 140.1 \\
\hline
\end{tabular}

a The calculation of the rate of coverage of each group of products and of the total has been made for each period as the average of the respective annual rates.

Source: Own calculation based on Estadísticas del Comercio Exterior de España, 1849-1935.

As we have seen, exports were concentrated in a series of products and played a fundamental role for the expansion of the production of these products. In spite of this, however, the diversification of the exported products was noteworthy (Table 1). In these cases, there were also certain significant linkages with other economic activities. On the one hand there were some significant backward linkages. They favoured the 
modernisation of agriculture, driving technological change, such as the use of inorganic fertilizers for MHPs, the use of chemicals to fight against vine plagues or the rapid implementation of vineyard reconstitution methods after the arrival of the phylloxera plague. Furthermore, they also fostered the formation of fixed capital with irrigation, the fuelling of the chemical fertilizer industry, the manufacture of containers, the improvement of port infrastructures for MHPs or railways in the vineyards (Calatayud, 2011). The boost to irrigation works is particularly important. On the Mediterranean coast new canals were constructed (Ramon-Muñoz, 2013) and wells were drilled to convert rainfed land into irrigated land. Overall, we could say that the development of the irrigation works was important. The use of irrigation water for exported agricultural products increased by $116 \%$ between 1860 and 1930 and the water needs of these export crops represented $31 \%$ of the increase in irrigation water embodied in agricultural production (Duarte, Pinilla and Serrano, 2014) ${ }^{7}$.

With respect to the forward linkages, these were also positive, although moderate. A part of the output exported corresponded to transformed products, which also implied the development of activities of the agro-food industry, in some cases generating a modernisation of the traditional facilities used ${ }^{8}$. In the case of wine, the progress was very uneven, focused particularly on the renovation of the presses used. In the production of olive oil more relevant changes occurred; on the one hand the machinery traditionally used was substantially renovated and, on the other hand from the beginning of the century the mills were electrified (Zambrana, 1987). Furthermore, after the First World War, new oil refining technology enabled oils that had high acidity levels and were not suitable for consumption to enter international markets. In this way a certain industrial infrastructure was developed. It could be said that, particularly after 1914, the Spanish oil industry experienced an intense modernisation process, enabling it to converge technologically with Italy, which was the world leader (Ramon-Muñoz, 2016). The majority of MHPs were exported with a low level of transformation, but even so, the preparation of the products generated positive effects which, for example in the case of oranges increased the price earned by the producer by $56 \%$ before they left Spain (Simpson, 1992, pp. 135136). An interesting industrial development also took place with the packaging of fruits and vegetables and the growth of the canning industry (Martínez-Carrión, 1989).

\footnotetext{
7 To make these calculations the blue water used has been taken, that is, the volume of surface or groundwater evaporating as a result of the production of a commodity (Hoekstra and Chapagain, 2008).

${ }^{8}$ See Martínez Carrión (2002) for the case of the agro-food industry in Murcia.
} 
For exports as a whole, there were very positive spillover effects of final demand, depending, logically, on the activities and the position of the producers in the value chain. Both the profits earned through export activities and the higher wages paid in some of them, when their productivity was higher than that of crops intended for the domestic market, favoured an increase in the demand for goods of other sectors introduced by industrial development. This was particularly true when the degree of the concentration of the export activities was geographically high, as in the case of the MHPs in Valencia (Palafox, 1996). The industrial activities that were boosted included textiles, footwear or furniture (Calatayud, 2011)

We could conclude that, as indicated by Prados de la Escosura (1982, p. 19) for Spanish trade as a whole, despite the moderate size of the export sector, it favoured economic development, enhancing the purchasing power of the economy and increasing real income through the improvement of resource allocation, as the comparative advantages of agriculture were taken advantage of, particularly in certain sectors, and factors of production were used more efficiently. This idea coincides with the perspective of Federico (1988, pp. 190-192 and 1992, pp. 290) who observed for Spain and Italy substantially positive microeconomic dynamic effects of production for exports, even when they were limited by the relatively small size of the export sector.

The territorial impact of these effects was varied but in general there was a high geographical concentration. In the case of wine, despite the broad geographic distribution of production, there was a high concentration in the regions close to the coast and to France. As wine was a highly consumed product in the domestic market, its production was enormously dispersed throughout the country. However, the expansion of production generated by exports to France was highly concentrated in the region of the Ebro valley which was on the border and well communicated with France and the Mediterranean coast. In 1891, the highpoint of wine exports, of the eight provinces that produced over one million hectolitres seven were located in these two regions and represented $52 \%$ of Spain's production.

In olive oil, there was higher concentration (especially in some areas of Andalusia and Aragon-Catalonia). Therefore, in 1933, only four provinces of Andalusia (Córdoba, Jaén, Málaga and Sevilla) represented $41 \%$ of the value of its production. In this case, it was not the proximity to the export markets that was the key factor explaining this location, but the agro-climatic conditions for the development of olive cultivation. 
In MHPs, there was a high concentration on the Mediterranean coast. If we take oranges, the most important export product in the first third of the twentieth century, their production was extremely concentrated. In 1934, only four provinces of the Mediterranean coast (Alicante, Castellon, Murcia and Valencia) represented $82 \%$ of the value of its production and only one of them (Valencia) 43\%. In MHPs, the location of the principal exporting regions could be explained both by their easy access to sea ports and the conditions for the cultivation of these products.

\section{Conclusions}

The Spanish agricultural export sector was a key element in the international integration of the Spanish economy during the first wave of globalisation. It represented a very large part of total Spanish exports and grew significantly, at a similar rate to global agricultural trade as a whole. Its behaviour was more dynamic that that of production intended for the domestic market and therefore its share of production increased from the mid nineteenth century until the years leading up to the Second World War. When broken down by product, the behaviour of agricultural exports was very diverse. In particular, three products stand out for their importance throughout the whole period: wine, MHPs and olive oil. Furthermore, the former two dominated the growth of exports in the second half of the nineteenth century and the first third of the twentieth century, respectively. They also gained very important positions in international markets.

We have shown that, although the growth of agricultural exports was not the key factor for the expansion of production, it made a significant contribution. Furthermore, the contribution of the three afore-mentioned groups of products was essential.

Agricultural exports grew thanks to the boost received from external demand, but also due to relevant changes made in the supply as a consequence of the higher relative returns of the export crops and the competitiveness reached in international markets. The fall in trade costs also favoured export growth, as did trade liberalisation, particularly in the second half of the nineteenth century.

However, a higher growth of agricultural exports was limited by the fact that some of the principal export products did not become products of mass consumption that were highly integrated in the diets of the populations of countries whose income grew the most due to the good rhythm of their industrialisation processes, as in the case of wine and 
olive oil. The growing protectionism in some markets from the end of the nineteenth century such as those in the America continent, or France for wine, affected the performance of the export sector.

It may be concluded that the contribution of the agricultural export sector to Spain's economic growth was positive although moderate. It contributed to financing necessary imports during the industrialisation process, it favoured a more efficient allocation of resources and produced intersectoral linkages. However, the geographic concentration of production for export spatially limited its impact on the Spanish economy.

\section{References}

Anderson, K., Meloni, G. \& Swinnen, J. (2018). Global Alcohol Markets: Evolving Consumption Patterns, Regulations, and Industrial Organizations. Annual Review of Resource Economics, 10, 105-113.

Anderson, K. \& Pinilla, V. with the assistance of A.J. Holmes (2017). Annual Database of Global Wine Markets, 1835 to 2016. University of Adelaide, Wine Economics Research Centre, https://www.adelaide.edu.au/wine-econ/databases/global-winehistory/.

Anderson, K., Nelgen, S. \& Pinilla, V. (2017). Global wine markets, 1860 to 2016: A statistical compendium, Adelaide: University of Adelaide Press.

Anderson, K. \& Pinilla, V. (Eds.). (2018). Global overview. In Wine Globalization: A New Comparative History. New York: Cambridge University Press.

Aparicio, G., González, A.L., Pinilla, V. \& Serrano, R. (2018). The world periphery in global agricultural and food trade, 1900-2000. In V. Pinilla and H. Willebald (Eds.), Agricultural Development in the World Periphery: A Global Economic History Approach (pp. 24-54), pp. 63-88. London: Palgrave-Macmillan.

Ayuda, M. I., Ferrer-Pérez, H. \& Pinilla, V. (2019). A leader in an emerging new international market: The determinants of French wine exports, 1848-1938. The Economic History Review. Advance online publication: https://onlinelibrary.wiley.com/doi/epdf/10.1111/ehr.12878 
Bringas, M.A. (2000). La productividad de los factores en la agricultura española (17521935). Madrid: Banco de España.

Bromhead, A., Fernihough, A., Lampe, M. \& O'Rourke, K. H. (2019). When Britain Turned Inward: The Impact of Interwar British Protection. American Economic Review, 109, 325-352.

Calatayud, S. (2011). Desarrollo agrario e industrialización. Crecimiento y crisis en la economía valenciana del siglo XX. Historia Contemporánea, 42, 105-147.

Calatayud, S. \& Martínez-Carrión, J.M. (1999). El cambio técnico en los sistemas de captación e impulsión de aguas subterráneas para riego en la España Mediterránea. In R. Garrabou and J. M. Naredo (Eds), El Agua en los Sistemas Agrarios. Una Perspectiva Histórica (pp. 15-40). Madrid: Fundación Argentaria.

Calatayud, S. \& Martínez-Carrión J.M. (2005). El cambio tecnológico en el uso de las aguas subterráneas en la España del siglo XX. Un enfoque regional. Revista de Historia Industrial, 28, 81-114.

Chevet, J. M., Fernandez, E., Giraud-Héraud, E. \& Pinilla, V. (2018). France. In K. Anderson and V. Pinilla, (Eds.), Wine Globalization: A New Comparative History (pp. 55-91). New York: Cambridge University Press.

Clar, E. \& Pinilla, V. (2009). The contribution of agriculture to Spanish economic development In P. Lains y V. Pinilla (Eds.), Agriculture and Economic Development in Europe since 1870 (pp. 311-332). Londres: Routledge.

Duarte, R., Pinilla, V. \& Serano, A. (2014). The effect of globalization on water consumption: A case study of the Spanish virtual water trade, 1849-1935. Ecological Economics, 100, 96-105.

Dunlevy, J. \& Hutchinson, W.K. (1999). The Impact of Immigration on American Import Trade in the Late Nineteenth and Early Twentieth Centuries. Journal of Economic History, 59, 4, 1043-1062.

Estadísticas del Comercio Exterior de España, 1849-1935, Madrid.

Federico, G. (1988). Commercio estero e "periferie". Il caso dei paesi mediterranei. Meridiana, 4, 163-196. 
Federico, G. (1992). El comercio exterior de los paises mediterráneos en el siglo XIX. In L. Prados de la Escosura \& V. Zamagni (Eds.), El desarrollo económico de la Europa del Sur: España e Italia en perspectiva histórica (pp.269-292). Madrid: Alianza Editorial.

Fernández, A. (2004). Un 'mercado étnico' en el Plata. Emigración y Exportaciones españolas a la Argentina, 1880-1935. Madrid: CSIC.

Gallego, D. (2001). Historia de un desarrollo pausado: integración mercantil y transformaciones productivas de la agricultura española. In J. Pujol et al. (Eds.), El pozo de todos los males. Sobre el atraso en la agricultura española contemporánea (pp. 147-214). Barcelona: Crítica.

Gallego, D. \& Pinilla V. (1996). Del librecambio matizado al proteccionismo selectivo: el comercio exterior de productos agrarios en España entre 1850 y 1935. Revista de Historia Económica, XIV, 2, 371-420 and 3, 619-639.

Garrabou, R. (1985). Un fals dilema.Modernitat o endarreriment de l'agricultura valenciana 1850/1900. Valencia: Institució Alfons el Magnànim.

Garrido, S. (2010). Oranges or "Lemons"? Family Farming and Product Quality in the Spanish Orange Industry, 1870-1960. Agricultural History, 84, 224-243.

González de Molina, M. (2001). Condicionamientos ambientales del crecimiento agrario español. In J. Pujol et al. (eds.), El pozo de todos los males. Sobre el atraso en la agricultura española contemporánea (pp. 43-94). Barcelona: Crítica.

Grupo de Estudios de Historia Rural (1983). Notas sobre la producción agraria española. Revista de Historia Económica, I, 2, 185-254.

Grupo de Estudios de Historia Rural (1991). Estadísticas Históricas de la producción agraria española, 1850-1935. Madrid: Ministerio de Agricultura.

Hernández, R. \& Pinilla, V. (2013). Del hambre a la abundancia: las crisis agrarias. In F. Comín and M. Hernández (eds.), Crisis económicas en España, 1300-2012 (pp. 5481). Madrid: Alianza Editorial.

Hoekstra, A.Y. \& Chapagain, A.K. (2008). Globalization of water: sharing the planet's freshwater resources. Oxford: Blackwell. 
Hynes, W., Jacks, D.S. \& O'Rourke, K.H. (2012). Commodity market disintegration in the interwar period. European Review of Economic History, 16, 119-143.

Jiménez Blanco, J. I. (1986). Introducción. En R. Garrabou, C. Barciela y J.I. Jiménez Blanco (Eds.), Historia agraria de la España contemporánea, 3. El fin de la agricultura tradicional (1900-1960) (pp. 10-141). Barcelona: Editorial Crítica.

Lachiver, M., (1988). Vins, vignes et vignerons. Histoire du vignoble français. Lille: Fayard.

Lains, P. \& Pinilla, V. (2009). Introduction, in P. Lains and V. Pinilla (eds.) Agriculture and Economic Development in Europe since 1870 (pp. 1-24). London: Routledge.

Lana, J.M. (2011). La productividad total de los factores en la agricultura española: el caso del sur de Navarra, 1780-1900. Revista de Historia Económica - Journal of Iberian and Latin American Economic History, XXIX, 3, 425-460.

Loubère, L. (1978). The Red and the White. A History of Wine in France and Italy in the Nineteenth Century. Albany: State University of New York Press.

Maravall, L. (2019). Factor endowments on the 'frontier': Algerian settler agriculture at the beginning of the 1900s. The Economic History Review, Advance online publication: https://doi.org/10.1111/ehr.12882.

Martínez-Carrión, J.M. (1989). Formación y desarrollo de la industria de conservas vegetales en España, 1850-1935. Revista de Historia Económica - Journal of Iberian and Latin American Economic History, 7, 619-649.

Martínez-Carrión, J.M. (2002). Historia económica de la región de Murcia. Siglos XIX y $X X$. Murcia: Consejería de Educación y Cultura.

Nadal, J. (1975). El fracaso de la Revolución industrial en España, 1814-1913. Barcelona: Ariel.

Neumark, S.D. (1938). The Citrus Industry of South Africa. Johannesburg: Witwatersrand University Press.

Palafox, J. (1983). Estructura de la exportación y distribución de beneficios. La naranja en el País Valenciano (1920-1930). Revista de Historia Económica, 2, 339-351.

Palafox, J. (1996). Expansión de las Exportaciones, Crecimiento, Diversificación Industrial e Industrialización. In J. Azagra, E. Mateu and J. Vidal (Eds.), De la 
sociedad tradicional a la economía moderna. Estudios de Historia Valenciana Contemporánea (pp. 321-345). Alicante: Instituto de Cultura Juan Gil Albert.

Pan-Montojo, J. (1994). La bodega del mundo. La vid y el vino en España (1800-1936). Madrid: Alianza Editorial.

Pinilla, V. (1995). Cambio agrario y comercio exterior en la España contemporánea, Agricultura y Sociedad 75, 153-179.

Pinilla, V. (2001). El comercio exterior en el desarrollo agrario de la España contemporánea: un balance. Historia Agraria, 23, 13-35.

Pinilla, V. \& Ayuda, M.I. (2002). The political economy of the wine trade: Spanish exports and the international market, 1890-1935. European Review of Economic History 6, 51-86.

Pinilla, V. \& Ayuda, M.I. (2008). Market dynamism and international trade in Mediterranean agricultural products, 1850-1935. Applied Economics, 40, 583-595.

Pinilla, V. \& Ayuda, M.I. (2009). Foreign markets, globalization and agricultural change in Spain, 1850-1935. In V. Pinilla (Ed.), Markets and agricultural change in Europe from the 13th to the 10th century. Turnhout: Brepols Publishers.

Pinilla, V. \& Ayuda, M.I. (2010). Taking advantage of globalization? Spain and the building of the international market in Mediterranean horticultural products, 1850 1935. European Review of Economic History 14, 239-274.

Pinilla, V. \& Serrano, R. (2008). The agricultural and food trade in the first globalization: Spanish table wine exports 1871 to 1935 - A case study. Journal of Wine Economics 3, 132-148.

Prados de la Escosura, L. (1982). Comercio exterior y crecimiento económico en España, 1826-1913: tendencias a largo plazo. Madrid: Banco de España.

Prados de la Escosura, L. (1988). De imperio a nación. Crecimiento y atraso económico en España (1780-1930). Madrid: Alianza.

Prados de la Escosura, L. (2003). El progreso económico de España (1850-2000). Madrid: Fundación BBVA. 
Ramon-Muñoz, R. (2000). Specialization in the international market for olive oil before world war II. In S. Pamuk, and J. G. Williamson (Eds), The Mediterranean Response to Globalization Before 1950 (pp. 159-198). London: Routledge.

Ramon-Muñoz, R. (2010). Globalisation and the international markets for Mediterranean export commodities: the case of olive oil, 1850-1938. Ph. D dissertation, European University Institute, Florence.

Ramon-Muñoz, R. (2016). Modernizing the Mediterranean olive-oil industry, 18501930s. In D.J. Oddy and A Drouard (Eds.), The food industries of Europe in the nineteenth and twentieth Centuries (pp. 71-90) London: Routledge.

Ramon- Muñoz, J. M. (2013). Cambio agrario, uso del suelo y regadío: el impacto del Canal de Urgell, 1860-1935. Historia Agraria, 59, 43-94

Roncales, V. (1998). Propiedad y riesgo en los inicios de la expansión citrícola valenciana durante el último tercio del siglo XIX. Historia Agraria, 16, 183-208.

Sánchez, A. (1992). La integración de la economía almeriense en el mercado mundial (1778-1936). Almería: Instituto de Estudios Almerienses.

Serrano, J.M. (1987). El viraje proteccionista en la Restauración. La política comercial española (1875-1895). Madrid: Siglo XXI de España Editores.

Silvestre, J. (2005). Internal migrations in Spain, 1877-1930. European Review of Economic History, 9, 233-265.

Simpson, J. (1992). Los límites del crecimiento agrario: España, 1860-1936. In Prados de la Escosura, L., Zamagni, V. (Eds), El desarrollo económico en la Europa del sur: España e Italia en perspectiva histórica (pp. 103-138). Madrid: Alianza Editorial.

Simpson, J. (1994). La producción y la productividad agraria española, 1890-1936, Revista de Historia Económica, 12,1, 43-86.

Simpson, J. (1995). Spanish Agriculture: the Long Siesta, 1765-1965. Cambridge, UK: Cambridge University Press.

Tena, A. (1989). Comercio exterior. In A. Carreras (Ed.) Estadísticas Históricas de España. Siglos XIX y XX (pp. 327-361). Madrid: Banco Exterior de España. 
Tena, A. (1992). Protección y competitividad en España e Italia, 1890-1960. In Prados de la Escosura, L., Zamagni, V. (Eds), El desarrollo económico en la Europa del sur: España e Italia en perspectiva histórica (pp. 321-358). Madrid: Alianza Editorial.

William H., David S. J. \& O'Rourke, K. H. (2012). Commodity market disintegration in the interwar period. European Review of Economic History, 16, 119-143.

Zambrana, F. (1987). Crisis y modernización del olivar español, 1870-1930. Madrid: Ministerio de Agricultura, Pesca y Alimentación. 